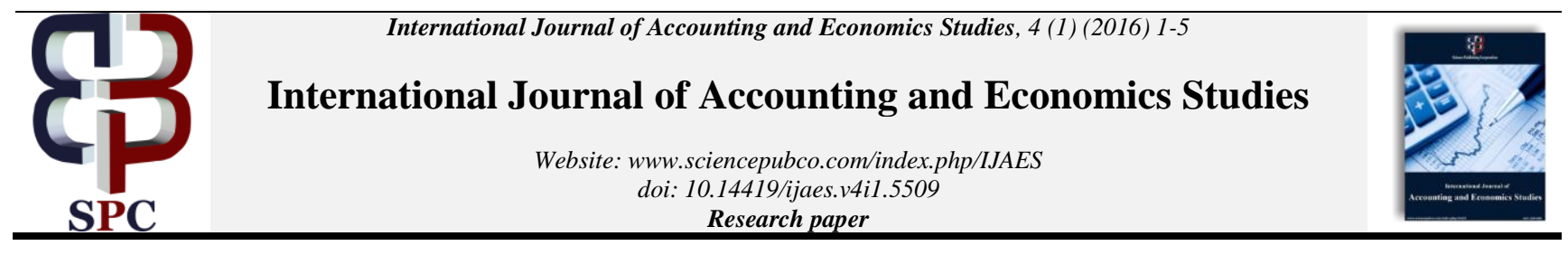

\title{
Quality of financial reporting: approaches to measuring
}

\author{
Jurij Renkas $^{1 *}$, Olena Goncharenko ${ }^{2}$, Olena Lukianets ${ }^{2}$ \\ ${ }^{1}$ Department of Accounting, Cracow University of Economics, Rakowicka St., 27, 31-425, Cracow, Poland \\ ${ }^{2}$ Department of Accounting and Audit, Cherkasy educational-scientific institute of the Banking University, \\ st. V. Chornovil, 164, 18-028, Cherkasy, Ukraine \\ *Corresponding author_E-mail: goncharenko_elen@mail.ru
}

\begin{abstract}
Financial reporting must meet many criteria to be considered high quality because it is the quality of information that determines the viability of future strategic decisions. The article investigates the essence of the concept of "quality" and "quality of financial information", and defines indicators and criteria of the financial reporting quality. As for the quality of the financial reporting, it is found that the latter is a structured reflection of financial condition and financial results of the entity, therefore, can be regarded as a set of components: quality of the financial information; quality of presentation of the financial information. It was found that the quality of the reporting of financial information is evaluated using a system of indicators that are qualified by the Financial reporting framework as the qualitative characteristics of useful financial information and National Accounting Statement (standard) 1 as the qualitative characteristics of financial reporting. In terms of formalization (presentation within the legislation forms) of the financial information presentation in Ukraine, we can speak of quality only in respect of the notes to the financial statements. It has been established that quality assessment indicators of presenting the financial information in the notes may be: readability of the information, visualization of the representation. Research of the quality requirements for the financial statements (information) of the participating countries of the former Soviet Union has identified many variations, but the most commonly used features are relevance, reliability, comparability and understandability. It is indicated that most post-Soviet countries, including Ukraine, gradually bring its legislation on the regulation of financial statements in conformity with IFRS. But there are still many unresolved differences, chief among which are the qualitative characteristics of the financial statements that should provide the information needs of different user groups.
\end{abstract}

Keywords: Quality; Criteria of Quality; Financial Reporting; Financial Reporting Standards.

\section{Introduction}

Today, reporting is the only institutional mechanism in Ukraine to assess the efforts of companies in the field of accounting and highlight best practices, competitions and rankings. However, none of the existing competition does not answer the question, what is the best practice of reporting and which quality parameters (criteria) must be met by the company reporting. This uncertainty in the quality parameters (criteria) leads to inhibition of corporate reporting in Ukraine and should be overcome.

Quality as a philosophical category was investigated by such scientists and philosophers like Aristotle, G. W. F. Hegel, René Descartes, Thomas Hobbes, John Berkeley, David Hume, Immanuel Kant, Karl Marx, Friedrich Engels, R. Boyle, John Locke. The theme of the quality of financial information has been examined as by domestic scientists, such as M.S. Pushkar, so as foreign scientists, among them the quality parameters were researched by G.G. Azhaldov, E.P. Reichman, E.S. Sokolova, Ferdy van Beest, Geert Braam, Suzanne Boelens. The issue of assessing the quality of accounting (financial) information is given considerable attention in the International Financial Reporting Standards and the Accounting National Policy (Standards) of Ukraine.

The task of the article is to study the financial information quality definitions and financial reporting quality indicators and criteria determination that should provide information needs for the dif- ferent user groups for the adoption of effective and efficient economic decisions.

\section{Analysis of recent research}

The philosophical "quality" category reflects the substantial certainty of things and phenomena of the real world. Quality certainty of things and the differences between them is externally expressed through properties. These properties are learned via feelings that reflect certain aspects, features and characteristics of things. Because of the feeling we first compare and distinguish things from each other, and reveal their different properties.

Intuitively clear idea of the quality was first formulated by Aristotle, who considered quality as a species difference of essence. He distinguished quality and features, emphasizing the holistic nature of the properties possessed by the thing. For the philosophy of mechanistic materialism of modern times, separation of qualities into primary and secondary has been expanded; the separation was introduced by R. Boyle and developed by John Locke in this work "Essay Concerning Human Understanding" (1690). Locke attributed length, size, position (location), mechanical movement, etc. to the primary qualities that exist objectively, regardless of the subject. The secondary qualities he called subjective qualities that do not match the properties of things themselves (color, smell, taste, etc.). This separation of the qualities takes its origin from the Democritus atomic hypothesis, according to which primary characteristics are atoms characteristics, and the secondary are their 
properties that are learned by means of the senses, while knowledge of atoms has intelligible character. This view of the existence of primary and secondary qualities have been widely recognized as in the natural science of XVII-XVIII century, so as in the oriented to it metaphysical materialism.

Galileo believed reliable only qualities that can be expressed geometrically, Descartes - qualities that have length, Hobbes - length and movement. They emphasized that primary qualities are learned by sense, though John Locke believed that they arise due to feelings. J. Berkeley rejected the objective existence of primary qualities, considering them as well as secondary qualities solely the result of subjective consciousness. David Hume and Immanuel Kant, denying the connection between phenomenon and essence, feeling and sense, held half-way position. While they, especially Kant, assumed objective existence of things, and therefore their quality, they denied the possibility of their knowledge of themselves: they can be known only in the form in which they appear to us. G. W. F. Hegel regarded quality as the initial stage of the absolute idea and knowledge of life. He defined quality as something, due to the loss of which a thing ceases to be itself. This purely negative definition opens possibilities for various interpretations.

Dialectical materialism is based on the recognition of objectivity and universality of qualitative certainty of things. The quality of the object appears in the totality of its properties. Herewith, the object does not consist of properties, is not some kind of "bundle of properties" but possesses them: "... there are not quality, but things that have qualities, and there is endless quantity of those qualities" (Marks, Engels). The quality is considered as a way of manifestation of a particular side of the object quality relative to the other objects with which it interacts. Category of the object quality not limited to certain of its properties. It expresses a complete description of the functional unity of the existing properties of the object, its internal and external certainty, relative stability, its differences from other objects or similarities (Philosophy: Encyclopedic Dictionary, 2006; Philosophical Encyclopedic Dictionary, 1983; New Encyclopedia of Philosophy, 2001). Quality category expresses a degree of man's knowledge of objective reality. At the initial stage of knowledge, the object of research stands out in relation to the subject by means of any particular property or set of properties. In a direct sense perception, the quality acts as a set of properties.

For a long period of time, the concept of quality in economic sciences was applied to material objects. But over time, the attention of scientists has moved from material production to the sphere of information and information systems. It is particularly importan to point out that the accounting is pure and simple the part of the overall information system that transforms the raw data recorded in the documents into a management product. Such a product is processed information, which has all the properties of the product. From this point of view, the accounting is the means of production of goods of a special kind - information that has value, cost, price, and other categories of commodity production (Pushkar, 2007), including quality.

For the first time the qualitative characteristics of accounting (financial) information have been discussed by the economists of leading economic countries as part of the creation of international financial reporting standards (IFRS). This document was first formulated and proved the qualitative characteristics of financial information. Thus, the quality of accounting (financial) information was used for the first time as an economic category.

\section{The presentation of the main ideas}

Talking about the quality of financial reporting is has to be understood that the latter is a structured display of the financial state and financial performance of the company (IAS 1 "Presentation of Financial Statements"), hence can be considered as a set of components:

- The quality of presentation of financial information;
- The quality of financial information.

As for the quality of presentation of the financial information, it is necessary to take into account the requirements of the National Accounting Statement (standard) 1 (hereinafter - NAS 1) "General requirements for financial reporting", which provides form and structure of financial statements. The same standard defines the financial statements: balance sheet (statement of financial state), income statement (statement of comprehensive income), statement of cash flows, statement of changes in equity and notes to the financial statements.

However, NAS 1 provides only the shape and composition of items for the first four financial statements, and non-formalized notes to the financial statements, as they are a set of indicators and explanations that provide a detailed justification of items of financial statements, and other information, disclosure is required by applicable National Accounting Statements (standards) or International financial reporting standards (hereinafter - IFRS). Although the order of the Ministry of Finance of Ukraine of 29.11.2000 № 302 "Notes to the annual financial statements" defined standard form of financial reporting № 5 "Notes to the annual financial statements" with certain reservations regarding additional disclosure of information provided by NAS 1 and not disclosed in the form, as well as non-use of the specified form by banks, public institutions, branches of foreign business entities, small businesses established in accordance with the law, and businesses that, in accordance with the legislation, prepare financial statements under international financial reporting standards.

So, in terms of formalization (representation in the legislation forms) presentation of financial information discussing the quality can only be possible in terms of the notes to the financial statements. Considering the quality of the set of properties, in assessing the quality of financial reporting, another term "indicator" (certificate, proof, a sign of something) must be used. Indicators assessing the quality of presentation of financial information in the notes may be:

\section{- Readability of information}

- Visibility of representation.

Readability of financial information reporting can be evaluated using specific criteria (feature, basis, rule of taking decision to evaluate something as required), for example: the presence or absence of description of individual objects registered in certain paragraphs, previously referred to in the preamble to the notes, the selection of material information font, color, etc., presentation of financial statements in the form of brochures (in the case of publications), automatic leaving the financial statements to an appropriate descriptive part of the notes and vice versa (when forming electronic financial statements) etc. Visibility index of the presentation of financial information is caused by physiological properties of users. Therefore, the evaluation criteria in this case may be the presence of graphical information (pictures, tables, diagrams), ways of presentation (two-, three-dimensional drawings, diagrams, static or dynamic images), etc.

For each criterion of the quality evaluation of the financial information presentation, parameters can be set (quantitative quantities characterizing the properties for specific criteria), with which it can be possible to quantitatively calculate the quality of presentation of financial information. Methods, techniques and methodology to quantify the quality of any object, including the information, are determined by the branch of science named qualimetry (Azgaldov, Rayhman, 1972).

The quality of the financial information is also measured by a system of indicators that qualify Conceptual Framework for Financial Reporting (hereinafter - Conceptual Framework) as the qualitative characteristics of useful financial information and NAS 1 as the qualitative characteristics of financial reporting.

According to the Conceptual Framework, financial statements prepared acc. to IFRS should have fundamental and improving qualitative characteristics. Fundamental qualitative characteristics include: relevance; faithful representation. Improving qualitative characteristics include: comparability; verifiability; timeliness; understandability. 
Fundamental characteristics are binding characteristics of quality reporting of financial information. If the financial statement of the company does not satisfy at least one of them, it cannot be of high quality. Comparability, verifiability, timeliness and understandability - these four characteristics are intended to enhance the quality of relevant, truthful information submitted.

The concept of "improving quality characteristics" means that these characteristics do not replace the fundamental characteristics. Even if improving characteristics of financial statements are of high level, but at the same time the financial reporting devoids of relevance or true presentation, it may not be of high quality. Let's look at what each of the features represents and how a company can evaluate the quality of its reporting acc. to IFRS.

Information is relevant if it can affect users reporting during decision-making, wherein financial reporting of companies must not only and not so much represent the impact of events and facts that have occurred, but also contain forward-looking information. To this end, Conceptual Basis includes the concept of predictive value and confirmatory value. Thus, the information has predictive value if it helps users to assess possible effects of past, present and future events on future cash flows, and confirmatory value if it helps users to compare current performance and results from their preliminary estimates. Predictive value and confirmatory value of the financial information are interrelated concepts. Often, the information that has predictive value also has confirmatory value. Thus, the relevance of reporting should be determined by the following criteria: focus of the reporting to the future; availability of forecast information; the availability of information about the company and the potential risks; disclosure of the information on the influence of important past events on the company.

Information about the economic phenomenon is believed to be truly presented in the financial reporting if it has three characteristics: completeness, neutrality and the absence of errors. Completeness means availability of all the information about the economic phenomenon (including descriptions and explanations necessary), which is required by users for the comprehensive understanding. In some cases, a full description can, among other things, include information on the essential facts on the current status of certain assets and description of circumstances that might affect their condition.

Neutrality in presenting information means that the information should not underestimate or overestimate the role of a phenomenon, or do any accents that exaggerate or diminish the role of the event, or manipulate opinion of users of financial statements in any other way. At the same time, information neutrality does not imply that this information is of any value or presentation does not pursue any goals. On the contrary, Conceptual Foundations emphasize that the information presented in the financial statements should influence the decisions of users.

In order to assess the financial statements from position of neutrality, the company must compare the style and form of presentation of the information on favorable and adverse economic effects in the report. If the company has made emphasis on describing the results of favorable events (such as revenue growth) and only skin-deeply mentioned adverse events and trends (for example, significant and unjustified increase in administrative costs), the following statements cannot be considered as neutral.

The concept "absence of errors" implies not merely the absence of errors in the description of phenomenon, its misstatements or omissions, but requires absence of errors in the process of preparation. However, the concept "absence of errors" is not identical to the concept of "complete accuracy in all aspects". In describing some economic phenomena term accuracy is unsuitable (e.g. in case of assumptions that the company makes under uncertainty). But it can be said that this assumption has valid representation if the nature of the event is described clearly and completely, and if a company in its reporting: revealed the method that was used to calculate the cost of future cleanup costs; described all limitations and uncertainties that are taken into account in the calculation; prevented errors in the application of methods and the procedures necessary to determine the value of future costs. It should be noted that there are considered two types of errors that are possible in the accounting and reporting: 1) professional error, which is usually rare and can be done, for example, when reflecting economic transactions in the accounting system; 2) a system error that usually applies to all operations of the same type. Note that the absolute compliance of the reporting with all three characteristics of the truthful reporting is achievable in practice very often. However, every company should strive to ensure that the indicators prove true presentation of its financial statements to the maximum extent possible.

The criteria for assessing the quality of reporting in terms of true presentation may be: completeness and quality of information in the submitted financial statements describing the assumptions and estimates made by the company; completeness and clarity of the notes to the reporting of the disclosed information regarding accounting principles used by the company for the preparation of financial statements; uniformity and completeness of the presented reporting information on favorable and adverse economic effects.

The usefulness of financial reporting of the company for its users increases if the information contained in it is comparable with similar information for other periods (for other reporting dates). In addition, this information should be comparable with similar information contained in the reports of other enterprises of the industry. Comparability is necessary to perform regarding the disclosure of accounting principles and description of events and phenomena. To enhance the comparability of financial statements, the company can provide in the notes comparative data for certain important performance indicators for several periods. Even if such disclosures are not required by the standards, this step will be appreciated by the users of financial statements.

Attention should be paid also to the structure of the financial reporting. The logical and consistent structure of the reporting notes helps to make of work of the investors easier while conducting a comparative analysis of the reporting with the reporting documents of other companies, and comparability of the information is very essential for decision making by investors.

The level of the reporting comparability is also affected by consistency in the application of accounting principles from period to period. But sometimes companies have to make changes in accounting policies. For example, when it is required for IFRS or when the change to accounting policies will represent reliable and more relevant information about the company. Despite the fact that in these cases the principle of the sequence is broken, the quality of such reporting increases. But to make the reporting information comparable, the company should be guided by the requirements of IAS 8 "Accounting Policies, Changes in Accounting Estimates and Errors". Compliance with this standard provides comparability of indicators of past periods with the data of the reporting period.

According to the Conceptual Foundations, possibility of checking means that independent experts with different expertise and different experiences can reach a consensus on the fact that these financial reporting is presented truthfully. Herewith, complete agreement of independent experts is not necessary. In terms of IASB (International Accounting Standards Board), ability to check the quality of reporting does not mean that every phenomenon reflected in the statements can be expressed in only one specific value. Perhaps it will be a number of values or a specific value of a certain number. This does not preclude the possibility of verification the reporting.

The possibility of verification can be direct or indirect. The criterion for direct verification is external visualization and criterion for the indirect verification is analysis of used models, techniques, rules and methodologies. For example, physical recalculation of residues of goods in the warehouse is an example of direct verification and arithmetic calculation of the cost of storage residues an example of indirect verification.

Timeliness means that financial information about the company became available to users before it lost its value for making decisions. For the companies which shares are traded on the stock exchange, the deadline for submission of financial statements is 
set, but a simple observance of these terms is not a determining factor now. Many companies are still reporting deadlines and constantly work to reduce the reporting deadlines. In order to assess the timeliness of reporting positions, the company must compare the dates of their reporting with reporting deadlines of other companies that are parties to the same exchange. Usually the comparison is made with the other companies of the same geographical region of the same business areas. Thus, the criterion of timeliness can be the deadline for company financial statements.

The financial statements of the company should be understandable to users who have sufficient knowledge of business and economic activities of the company and analyze financial statements with due diligence and interest. The company shall strive to ensure that the information is presented in a simple, clear and structured manner. However, these criteria are difficult to implement as many economic phenomena are complex and their presentation in the financial statements in a simple and accessible way is not always possible. In assessing the clarity of its financial statements, the company has to pay attention to how simple and easy to under- stand the language that was used in the preparation of the notes to the reporting. The company shall ensure that creating the notes no professional slang was used. If the company uses special terms, this necessitates a special section with their explanation.

In order to understand if the information in the notes to the reporting is disclosed correctly, these notes can be submitted for assessing to the several experts in the company. Then the conclusions that experts make based on notes should be compared. If the conclusions are identical in content and are in line with what the company saw as the need to disclose in the notes, then the information is clear.

NAS 1 indicates the following qualitative characteristics of financial statements as clarity and understandability, relevance, reliability, comparability, disclosure of the information of the accounting policies and changes that to some extent repeat the above IFRS characteristics. Besides Ukraine, the legislation of most countries - members of the former Soviet Union also defines requirements for the quality of financial reporting (Table 1).

Table 1: Matrix Structure of Qualitative Characteristics of Financial Statements

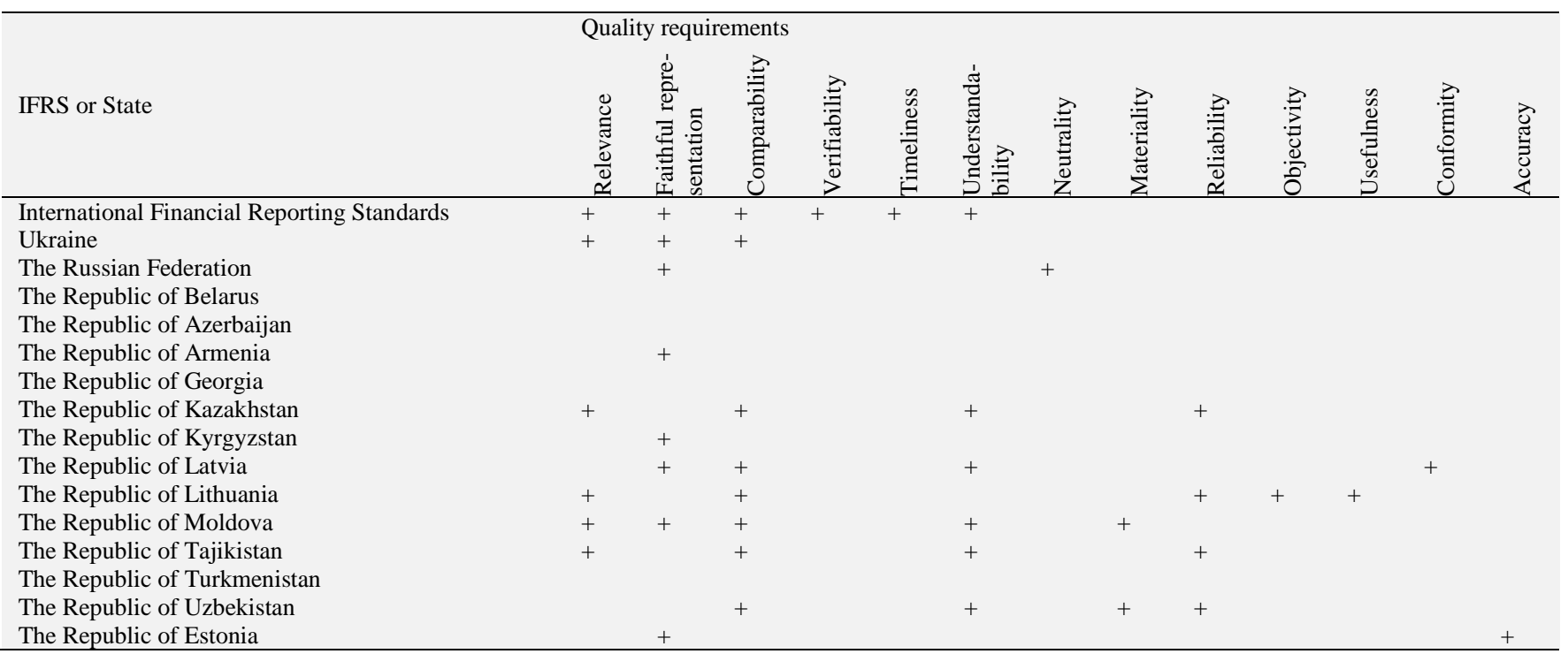

Source: worked out base on the data [2], [3], [6], [7], [10-12], [14], [16-30].

Total requirements for the reporting quality include 13 titles; the most commonly used are relevance, reliability, comparability and understandability. It should be noted that in Belarus, Azerbaijan, Georgia and Turkmenistan qualitative characteristics of financial statements are not distinguished at all.

It can be noted that most post-Soviet countries gradually hold its legislation on the regulation of financial statements in conformity with IFRS. But there are still many unresolved differences, chief among which are the qualitative characteristics of financial statements that must meet the needs of users. The experience of postSoviet countries that have switched to IFRS should be used in the domestic economy, taking into account national circumstances, while economic relations require the application of convergence measures of financial reporting standards and approaches to their assessment.

\section{Conclusion}

Financial statements must meet many criteria to be considered of high quality. The quality of the financial information has great importance for different groups of users, especially for members of the business process, because the quality of information determines the viability of future strategic decisions. Due to the intensive development of a systematic approach to study and solving the problem of assessing the quality of financial reporting and the wide application of quality management systems, practical significance indicators, criteria and parameters of the financial infor- mation gain the increasing weight. The role of management in the preparation of high-quality reporting is increased. Therefore, to ensure the reporting quality control, many companies are forced to create new departments (such as the internal control) and view the structure and functionality of existing units.

\section{References}

[1] Azgaldov G.G., Rayhman E.P. (1972) Aabout qualimetry. 172 p. http://www.labrate.ru/azgaldov/azgaldov_raikhman_about_qualime try-1973.pdf.

[2] Business accounting standard №1 Republic of Lithuania "Financia Statements" http://www.finmin.lt/c/portal/layout?p_1_id=PUB.1.56

[3] Federal Law Russian Federation "On Accounting" № 402-FZ (06.12.2011). http://www.consultant.ru/document/cons_doc_LAW 170573/.

[4] Philosophy: Encyclopedic Dictionary / Edited Ivin A.A. (2006), $1072 \mathrm{p}$.

[5] Philosophical Encyclopedic Dictionary / Edited L.F. Ilichyov, P.N. Fedoseev, S.M. Kovalyov, V.G. Panov (1983), 840 p.

[6] Financial reporting framework. http://zakon4.rada.gov.ua/laws/show/929_009.

[7] Latvian Accounting Standard № 1 "Basic Principles of preparation of financial statements (05.02.2004).http://fm.gov.lv/?eng/accountancy

[8] Marks K., Engels F. (1963-1983) Writings. Vol. 20 
[9] Order The Ministry of Finance of Ukraine № 302 "On the notes to the annual financial statements (29.11.2000) http://search.ligazakon.ua/1_doc2.nsf/link1/REG5125.html.

[10] National Accounting Statement (standard) 1 "General requirements for financial reporting", approved by the Ministry of Finance of $\begin{array}{lll}\text { Ukraine } & \text { № } & 73\end{array}$ http://zakon4.rada.gov.ua/laws/show/z0336-13.

[11] National Accounting Standard of the Republic of Uzbekistan № 1 "Accounting Policies and Financial Statements" (14.08.1998). http://www.lex.uz/Pages/GetAct.aspx?lact_id=556789.

[12] National Accounting Standard of the Republic of Moldova "Presentation of Financial Statements" (01.01.1998). http://www.mf.gov.md/ru/actnorm/contabil/standarts.

[13] New Encyclopedia of Philosophy / Edited V.S. Styopina (2001).

[14] Policy Accounting of the Republic of Tadzhikistan № 5 "Accounting businesses" (16.07.2001). http://minfin.tj/bua.html.

[15] Pushkar M.S. (2007) Metatheory account or what should be the theory. Ternopil: Kart-blansh, 359 p.

[16] Law of the Republic of Belarus "About Accounting and reporting" № $57-3 \quad$ (12.07.2013). http://www.gb.by/izdaniya/glavnyibukhgalter/o-bukhgalterskom-uchete-i-otchetnosti-za.

[17] Law of the Republic of Azerbaijan "About Accounting" № 716-IIQ (29.06.2004). http://www.maliyye.gov.az/en/node/1001

[18] Law of the Republic of Armenia "About Accounting" № 515 (26.12.2002).

http://www.parliament.am/legislation.php?sel=show \&ID=1344\&la ng=rus.

[19] Law of the Republic of Georgia "About the regulation of accounting and reporting"» № 1796-II $\mathrm{R}$ (05.02.1999). http://www.mof.ge/en/tax_customs/legislation.

[20] Law of the Republic of Kazakhstan "About Accounting and Financial Statements" № 234-III (28.02.2007). http://online.zakon.kz/Document/?doc_id=30092011.

[21] Law of the Republic of Kyrgyzstan "About Accounting" № 76 (29.04.2002).

http://www.minfin.kg/index.php?option=com_content\&view=categ ory $\&$ id $=65 \&$ Itemid $=135$.

[22] Law of the Republic of Latvia "About Accounting" № 44 (14.10.1992). http://fm.gov.lv/?eng/accountancy.

[23] Law of the Republic of Latvia "About the annual reports of enterprises" № 45 (14.10.1992). http://fm.gov.lv/?eng/accountancy.

[24] Law of the Republic of Lithuania "About Accounting" № IX-574 (06.11.2001). http://www.finmin.lt/c/portal/layout?p_1_id=PUB.1.79.

[25] Law of the Republic of Lithuania "About the financial statements" № IX-575 (06.11.2001) http://www.finmin.lt/c/portal/layout?p_1_id=PUB.1.80.

[26] Law of the Republic of Moldova "About Accounting" № 113-XVI (27.04.2007). http://www.mf.gov.md/ru/actnorm/contabil/lawcontabil/.

[27] Law of the Republic of Tadzhikistan "About Accounting and finan$\begin{array}{llll}\text { cial statements" } & \text { № } & 702 & \text { (25.03.2011) }\end{array}$ http://mmk.tj/ru/legislation/legislation-base/2011/.

[28] Law of the Republic of Turkmenistan "About Accounting and financial statements" № 155 -IV $\quad$ (27.11.2010) http://online.zakon.kz/Document/?doc_id=31341522.

[29] Law of the Republic of Uzbekistan "About Accounting" № 279-I (30.08.1996). http://base.spinform.ru/show_doc.fwx?rgn=1043.

[30] Law of the Republic of Estonia "About Accounting" № 285 (10.12.2002). https://www.riigiteataja.ee/akt/12769864?leiaKehtiv. 